\title{
The Anaphor Agreement Effect in the nominal domain: Evidence from Turkish
}

\author{
Lefteris Paparounas \& Faruk Akkuş*
}

\begin{abstract}
We examine a set of agreement asymmetries in the Turkish nominal domain, motivating two core generalizations. Firstly, the assignment of genitive case yields an opacifying effect, making certain large nominals, but not pronouns, into domains inaccessible for agreement. Secondly, this opacifying effect is overridden in cases of binding: if an element that normally fails to agree acts as a binder, it can exceptionally participate in an agreement relationship. We examine the implications of these findings for recent proposals on the nature of the Anaphor Agreement Effect, and for the relationship between case, agreement, and binding.
\end{abstract}

Keywords. agreement; binding; anaphora; case

1. Introduction. In the Turkish nominal domain, pronouns and anaphors differ in terms of agreement: pronouns obligatorily trigger full nominal agreement, whereas anaphor fail to agree, yielding default third-singular agreement. This pattern is, descriptively, an instance of the Anaphor Agreement Effect (AAE; Rizzi 1990; Woolford 1999) that is at once generalized (in that it in fact involves non-anaphoric elements as well) and relativized (in that it occurs only with nominal, but not with verbal, agreement).

We provide evidence for two striking generalizations on this pattern. Firstly, the driving factor behind this agreement asymmetry is genitive case, which makes anaphors and other large nominals, but not pronouns, inaccessible for agreement. Secondly, binding overrides the opacifying effect of the genitive: if an element that normally triggers default agreement binds, it can agree. Taken together, these observations hint at important conclusions on the relationship between binding and agreement.

2. Default nominal agreement. In this section, we present an overview of the distribution of default agreement in the Turkish NP, and show that this pattern cannot be derived by the classical binding conditions alone, pace Kornfilt (2007).

2.1. The Basic Pattern. In Turkish possessive NPs and nominalized clauses, anaphors and pronouns dissociate with respect to their agreeement behavior. Illustrating first with possessive NPs, pronominal possessors obligatorily trigger co-varying agreement on the possessed noun. ${ }^{1}$
a.
Biz biz-im sınav-ımız-1
gör-dü-k.
we We-GEN ${ }^{2}$ exam-1PL.POSS-ACC See-PST-1PL.
'We saw our exam.'
b. * Biz biz-im sinav-ın-1 gör-dü-k.
we we-GEN exam-3sG.POSS-ACC See-PST-1PL.
'We saw our exam.'

\footnotetext{
* This work has benefitted from many discussions with Julie Anne Legate, David Embick, and Martin Salzmann. We are also grateful to Elena Anagnostopoulou, Sabine Iatridou, Jaklin Kornfilt, Alec Marantz, Deniz Özyıldız, and audiences at FMART, the Syntax Reading Group at Penn, the LSA 2020 Annual Meeting, and Tu+ 5 for feedback. Thanks also to Leyla Zidani-Eroğlu, Jaklin Kornfilt, Deniz Özyıldız, Uğurcan Vurgun, Hande Sevgi, Özlem Ergelen, Bülent Akkuş, Turan Akkuş, Ibrahim Yıldırım, Leyla Gülten, Mustafa Akbağ and Hasibe Gülen for their judgments. All errors remain our own. Authors: Lefteris Paparounas, University of Pennsylvania (lefteris@sas.upenn.edu) \& Faruk Akkuş, University of Pennsylvania (akkusf@sas.upenn.edu).

${ }^{1}$ All data in Section 2.1 are from Kornfilt (2007).
} 
However, anaphoric possessors are only grammatical with default third-singular agreement on the possessed noun. We illustrate here with the reciprocal birbir.
a. * Biz birbir-imiz-in
Sinav-ımız-1
gör-dü-k.

we each.other-1PL.POSS-GEN exam-1PL.POSS-ACC See-PST-1PL.

'We saw each other's exam.'

*[rec, 1PL]

b. Biz birbir-imiz-in sinav-ın-1 gör-dü-k.

we each.other-1PL.POSS-GEN exam-3sG.POSS-ACC See-PST-1PL.

'We saw each other's exam.'

[rec, 3sG]

In nominalized embedded clauses, the same pattern obtains. Anaphoric subjects trigger default third-singular agreement, whereas pronominal subjects trigger co-varying agreement: ${ }^{3}$

a. $\quad * \mathrm{Biz}_{i}\left[\right.$ birbir-imiz-in $_{i} \quad$ sınav-1 geç-tiğ-imiz ]-i

we each.other-1PL.POSS-GEN exam-ACC pass-FNMLZ-1PL.POSS -ACC

san-1yor-du-k.

believe-PROG-PST-1PL

'We believed that each other passed the exam.'

b. $\mathrm{Biz}_{i}\left[\right.$ birbir-imiz-in $_{i}$ sinav-1 geç-tiğ-in ]-i

we each.other-1PL.POSS-GEN exam-ACC pass-FNMLZ-3sG.POSS -ACC

san-1yor-du-k.

believe-PROG-PST-1PL

'We believed that each other passed the exam.'

[rec, 3sG]

(4) a. $\left(\mathrm{Biz}_{i}\right)\left[\mathbf{b i z}^{-i m_{i}} / \mathbf{p r o}_{i}\right.$ sınav-1 geç-tiğ-imiz ]-i san-1yor-du-k.

we We-GEN exam-ACC pass-FNMLZ-1PL.POSS -ACC believe-PROG-PST-1PL

'We believed that we passed the exam'

[pro, 1PL]

b. * $\left(\mathrm{Biz}_{i}\right)$ [ biz-im $_{i} /$ pro $_{i}$ sinav-1 geç-tiğ-in ]-i san-1yor-du-k.

you.PL we-GEN exam-ACC pass-FNMLZ-3sG.POSS -ACC believe-PROG-PST-1PL

'We believed that we passed the exam' *[pro, 3sG]

2.2. Against a binding-Based account. Kornfilt (2007) argues that the basic pattern described above should be reduced to the different binding-theoretic requirements of anaphors and pronouns. Though this work does not propose an explicit account to this end, the reasoning sketched is as follows.

Suppose that co-varying nominal agreement in a nominalized clause defines that clause as a binding domain for anaphors and pronouns (George \& Kornfilt 1981). As such, when these elements are subjects of a nominalized clause, they cannot be bound by matrix DPs. Hence, agreeing reciprocal subjects are not bound in their binding domain, violating whatever derives

\footnotetext{
${ }^{2}$ Glossing abbreviations: $1=$ first person, $2=$ second person, $3=$ third person, $\mathrm{ABIL}=$ abilitative, $\mathrm{ABL}=\mathrm{ablative}, \mathrm{ACC}=$ accusative, $\mathrm{AOR}=$ aorist, $\mathrm{COM}=$ comitative, $\mathrm{DAT}=$ dative, $\mathrm{FNMLZ}=$ factive nominalizer, $\mathrm{GEN}=$ genitive, $\mathrm{LOC}=$ locative, $\mathrm{NEG}=$ negative, $\mathrm{NFNMLZ}=$ non-factive nominalizer, $\mathrm{NOM}=$ nominative, $\mathrm{PL}=$ plural, $\mathrm{POSS}=$ possessive, $\mathrm{PROG}=$ progressive, $\mathrm{PST}=$ past, $\mathrm{SG}=$ singular.

${ }^{3}$ We illustrate with so-called factive nominalized clauses throughout; as Kornfilt (2007) notes, the same pattern obtains with non-factive and future nominalized clauses.
} 
Condition A of the classical Binding Theory (Chomsky 1981) and making examples such as (3a) ungrammatical. By contrast, agreeing pronouns are free within the binding domain, hence passing Condition B and resulting in grammatical sentences such as (4a). However, default agreement somehow extends the binding domain defined by the nominalized clause. In this scenario, embedded subjects can be bound in their domain, ensuring that anaphoric subjects pass Condition A (3b) and pronominal subjects violate Condition B (4b). Under this approach, then, agreement is the independent factor responsible for the observed pattern: certain agreement configurations will result in binding violations, whereas others will not.

Kornfilt (2007) is correct to point out that some consideration of binding is necessary to arrive at a full explanation of the pattern just described: it is clearly surprising that both reciprocals and pronouns can occur as subjects of nominalized clauses. However, we will show that the reasoning advanced in Kornfilt (2007) cannot be entirely on the right track. Two pieces of evidence suggest that binding alone cannot derive the asymmetric behavior shown by anaphors versus pronouns.

Firstly, referential pronouns occurring as subjects of nominalized clauses are ungrammatical with default agreement.
a. Ayşe [biz-im kek-i ye-diğ-imiz ]-e inan-1yor- $\varnothing$.
Ayşe.Nom we-GEN cake-ACC eat-FNMLZ-1PL.POSS -DAT believe-PROG-3sG
b. * Ayşe [biz-im kek-i ye-diğ-in ]-e inan-1yor- $\varnothing$.
Ayşe.nOM we-GEN cake-ACC eat-FNMLZ-3sg.Poss -DAT believe-Prog-3sg

'Ayşe believes that we ate the cake.'

These data are unexpected under a binding-based account of the agreement asymmetry. Recall that, in such accounts, pronouns are incompatible with default agreement because default agreement extends the binding domain, causing them to be bound by matrix DPs. But in (5), the embedded pronoun is clearly referential. Despite the fact that binding is thus not at stake, the pronoun is still ungrammatical with third-singular agreement.

Importantly, the binding-based approach also makes incorrect predictions as to the behavior of anaphors. Consider firstly that, as discussed by Legate et al. (2019), the Turkish reciprocal is a local anaphor, but the inflected reflexive kendi is a logophor.

a.

* [ Öğrenci-ler-in birbir-leri-ni ${ }_{i} \quad$ beğen-me-si
student-PL-GEN each.other-3PL.POSS-ACC admire-NFNMLZ-3sG.POSS
öğretmen-ler-in ${ }_{i}$ hoş-un-a git-ti- $\varnothing$.
teacher-PL-GEN liking-3sG.POss-DAT go-PST-3SG
'The students' admiring each other ${ }_{i}$ was to the teachers' ${ }_{i}$ liking.'
$2019 ; 13)$

b. [ Oya-nın kendi-si-ni $i_{i}$ beğen-me-si Ahmet-in $_{i}$ Oya-GEN self-3sg.POSs-ACC admire-NFNMLZ-3sG.POSs Ahmet-GEN hoş-un-a git-ti- $\varnothing$.

liking-3sG.POSs-DAT go-PST-3sG

'Oya's admiring self $i$ was to Ahmet ${ }_{i}$ 's liking.'

(Kornfilt 2001; 204)

Note now that, like the reciprocal, the inflected reflexive also disallows co-varying agreement. 
a. $\quad * \operatorname{Biz}_{i}\left[\right.$ kendi-miz-in ${ }_{i}$ sınav-1 geç-tiğ-imiz ]-i san-1yor-du-k. we self-1PL-GEN exam-ACC pass-FNMLZ-1PL -ACC believe-PROG-PST-1PL

b. $\quad \operatorname{Biz}_{i}\left[\right.$ kendi-miz-in ${ }_{i}$ sınav-1 geç-tiğ-in ]-i san-1yor-du-k. we self-1PL-GEN exam-ACC pass-FNMLZ-3SG -ACC believe-PROG-PST-1 PL

'We believed that ourselves passed the exam.'

(Kornfilt 2007: 321-322)

These data directly contradict the binding-based approach. We find that two anaphors, each with different binding-theoretic requirements, behave uniformly with respect to agreement; as such, whatever derives the agreement asymmetry cannot make direct reference to binding.

2.3. Beyond AnAPhORs. The class of NPs that trigger default nominal agreement includes anaphors, but other NPs as well. These NPs are not referentially deficient, and are thus not subject to binding-theoretic requirements; this allows us to easily test their behavior in matrix contexts. We in turn observe an important contrast: these NPs trigger default agreement in embedded nominalized contexts, but not in matrix contexts.

Let us begin with so-called ${ }^{4}$ partitive NPs like ikimiz 'two of us' and hepimiz 'all of us'. Partitives obligatorily trigger co-varying agreement when occurring as subjects of matrix clauses. ${ }^{5}$

Partitive - Matrix clause
a. Ikimiz gel-di-k.
two.of.us come-PST-1PL
b. * Ikimiz gel-di-Ø.
two.of.us come-PST-3sG

'Two of us came'

However, as noted by Ince (2008), partitives pattern with anaphors in triggering obligatory default agreement in nominalized embedded clauses.

(9) Partitive - Nominalized clause
a. * Çocuk [ ikimiz-in gel-diğ-imiz
]-i söyle-di.
child two.of.us-GEN come-FNMLZ-1PL.Poss -ACC Say-PST.3sG
b. Çocuk [ikimiz-in gel-diğ-in ]-i söyle-di.
child two.of.us-GEN come-FNMLZ-3sg.Poss -ACC Say-PST.3sG

'The child said that two of us came.'

Adnominal pronoun constructions (APCs) like we Turks pattern in the same way. In matrix clauses, they trigger co-varying agreement controlled by the pronoun.

\footnotetext{
${ }^{4}$ The term 'partitive' may be misleading here, in the sense that these NPs do not have an internal structure parallel to that of Indo-European partitives. For instance, the structure of ikimiz is as follows.

(i) iki miz

two 1PL.POSS

'two of us' (literally our two)

${ }^{5}$ Finite embedded clauses pattern identically to matrix clauses with respect to agreement for all purposes below; we present only matrix clauses for reasons of space.
} 
APC-Matrix clause

$\begin{array}{ll}\text { a. } & \text { Biz Türk-ler çok çalış-1r-1z. } \\ \text { we Turk-PL very work-AOR-1 PL } \\ \text { b. * } \quad \text { Biz Türk-ler çok çalış-1r-Ø. } \\ \text { we Turk-PL very work-AOR-3sG }\end{array}$

'We Turks work hard.'

In embedded nominalized clauses, however, APCs trigger default agreement.

(11) APC-nominalized clause

a. * [ Biz Türk-ler-in çok çalış-tığ-ımız ]-1 bil-ir-sin. we Turk-PL-GEN very work-FNMLZ-1PL.POSS -ACC know-AOR-2PL

b. [ Biz Türk-ler-in çok çalış-tı̆̆-ın ]-1 bil-ir-sin. we Turk-PL-GEN very work-FNMLZ-3sG.POSS -ACC know-AOR-2PL

'You know that we Turks work hard.'

The last set of items obeying this matrix/nominalized contrast are the inflected pronouns bizler and sizler. As background, consider that the regular first and second person plural pronouns, biz 'we' and siz 'you (pl.)', are portmanteau realizations of person and number. The forms bizler and sizler consist of the portmanteau forms affixed with the exponent -lAr, traditionally labeled the plural exponent; however, as biz and siz are already marked for number, the $-l A r$ in the inflected pronouns must be an exponent of some other category.

Importantly, this morphological difference between biz and siz on the one hand, and bizler and sizler on the other, maps onto divergent patterns of syntactic behavior with respect to agreement. In matrix clauses, the two sets of pronouns behave identically, obligatorily triggering co-varying agreement.

Regular pronoun - Matrix clause

a. Biz oraya git-ti-k. we there go-PST-1PL

b. * Biz oraya git-ti-Ø. we there go-PST-3sG

'We went there.'

Inflected pronoun - Matrix clause

a. Biz-ler oraya git-ti-k. we-LER there go-PST-1PL

b. * Biz-ler oraya git-ti-Ø. we-LER there go-PST-3SG

'We went there.'

But in nominalized embedded clauses, the two sets of pronouns diverge: $\mathrm{biz} /$ siz continue to trigger obligatory co-varying agreement, as seen repeatedly in many examples so far, whereas bizler/sizler trigger default agreement, thus patterning with anaphors, partitives and APCs. 
a. Kemal [ biz-im oraya git-tiğ-imiz ]-i san-dı- $\varnothing$.

Kemal we-GEN there go-FNMLZ-1PL.POSS -ACC think-PST-3sG

b. *Kemal [ biz-im oraya git-tiğ-in ]-i san-dı- $\varnothing$.

Kemal we-GEN there go-FNMLZ-3sg.POSs -ACC think-PST-3sG

'Kemal thought that we went there.'

Inflected pronoun - Nominalized clause

a. * Kemal [ biz-ler-in oraya git-tiğ-imiz ]-i san-dı- $\varnothing$.

Kemal we-LER-GEN there go-FNMLZ-1PL.POSS -ACC think-PST-3sG

b. Kemal [ biz-ler-in oraya git-tiğ-in ]-i san-dı-Ø.

Kemal we-LER-GEN there go-FNMLZ-3sG.POSS -ACC think-PST-3sG

'Kemal thought that we went there.'

The data from partitives, APCs and inflected pronouns are illuminating in three respects. Firstly, the fact that these elements trigger default agreement only in nominalized clauses suggests that default agreement must derive from some property specific to nominalized clauses. Secondly, the emergence of third-singular agreement only in the nominal domain eliminates the possibility, admissible in principle, that third-singular agreement is not a default, but rather regular agreement triggered by third-singular features residing somewhere in the structure of the relevant subjects. Finally, partitives, APCs and inflected pronouns are not subject to binding, and yet still trigger default nominal agreement, corroborating the conclusion above that binding alone cannot be responsible for the emergence of default agreement.

3. The role of the genitive. The data discussed so far raise two questions.

1. What is the property, shared by anaphors, partitives, APCs and inflected pronouns, that triggers default agreement? (We call these elements default-triggering NPs henceforth)

2. Why do these NPs only trigger default agreement in the nominal domain?

The core challenge posed by the Turkish data lies in the combination of these two questions. Anaphors, partitives, APCs and inflected pronouns must share some property, to the exclusion of pronouns, that triggers default agreement; at the same time, this property must trigger default agreement only when these elements are in the nominal domain.

We argue that a unified answer to both questions comes from an independent difference between nominalized and verbal clauses, namely, case-marking on the subject. Recall that the subjects of verbal clauses are nominative, whereas the subjects of nominalized clauses are genitive; we suggest that genitive case is the factor responsible for the emergence of default agreement in the nominal domain. Genitive case treats default-triggering NPs differently from pronouns, making the former, but not the latter, into domains opaque for agreement.

Striking evidence for the genitive as the factor deriving default agreement comes from an independent difference between adjunct and argument nominalized clauses. So far, we have only encountered nominalized clauses with genitive subjects; however, Kornfilt (2003) notes that the subjects of factive nominalized clauses must be nominative if the clause is an adjunct. 
a. Ben [ Ali-*(nin) cam-1 k1r-d1ğg-1 zaman ]-1 bil-iyor-du-m.

I Ali-GEN glass-ACC break-FNMLZ-3sG.POss time -ACC know-PROG-PST-1sG

'I knew when Ali broke the glass.'

b. Ben [ Ali-(*nin) cam-1 kır-dı̆̆-1 zaman ] gerçeğ-i

I Ali glass-ACC break-FNMLZ-3sG.POss time truth-ACC

bil-iyor-du-m.

knOw-PROG-PST-1sG

'I knew the truth when Ali broke the glass.'

(Aygen 2007; 2)

In (16a), the nominalized clause is an argument of the matrix verb knew, functioning as an embedded question; here, the subject must be genitive, as we have been seeing so far. Compare this state of affairs to (16b), where the nominalized clause is adjoined as a temporal adverb: here, the subject must be nominative. ${ }^{6}$

Strikingly, in adjunct nominalized clauses, where the subject must be nominative, defaulttriggering NPs trigger full agreement, thus patterning with pronouns.

a. [ [ Biz-(*im) yemek pişir-diğ-imiz ]-den dolayı ] konser-e

we food cook-FNMLZ-1PL.POSS -ABL because concert-DAT gid-e-me-di-m.

go-ABIL-NEG-PST-1SG

'Because we cooked, I was unable to go to the concert.'

(Kornfilt 2003: 151)

b. [ [ Biz-ler-(*in) yemek pişir-diğ-imiz ]-den dolayı ] konser-e

We-LER food cook-FNMLZ-1PL.POSS-ABL because concert-DAT

gid-e-me-di-m.

go-ABIL-NEG-PST-1sG

'Because we cooked, I was unable to go to the concert.'

Importantly, default agreement with a nominative-marked default-triggering NP is ungrammatical.

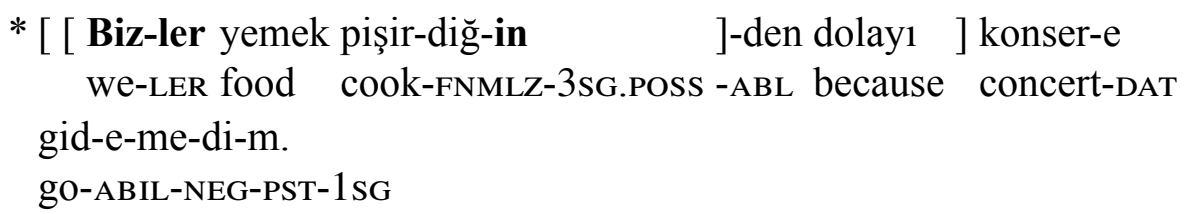

'Because we cooked, I was unable to go to the concert.'

In other words, when they receive genitive case, pronouns and default-triggering NPs dissociate: the latter, but not the former, trigger default agreement. But this dissociation is neutralized when they are marked with nominative case, as in verbal clauses and adjunct nominalized clauses. Genitive case, then, must be responsible for the emergence of default agreement. ${ }^{7}$

\footnotetext{
${ }^{6}$ Kornfilt (2003) notes that the same pattern does not obtain with non-factive clauses, whose subjects must always be genitive.

${ }^{7}$ This has been independently conjectured in Sat1k (2020), though the evidence in favor of this generalization mentioned here is not noted in this work. Satik does, however, offer a proposal as to why the genitive creates opaque domains; we postpone discussion of this proposal to Section 5.
} 
4. Binding/agreement interactions. At the center of this paper so far has been the observation that, when the subject of a nominalized clause is a genitive-marked anaphor, partitive, APC or inflected pronoun, the nominalized verb must bear default agreement. In this section, we introduce the only instance where this pattern is violated. When a default-triggering subject of a nominalized clause (e.g. a partitive NP) binds an element lower in the structure, the nominalized verb can receive either default or co-varying agreement. In other words, the possibility of co-varying agreement with a genitive-marked default-triggering subject - absent in all cases seen above - is licensed when the nominalized clause contains an element bound by the subject. Binding licenses the otherwise illicit possibility of full agreement.

To illustrate this pattern, let us contrast full unbound NPs with reciprocals in the object position of a clause whose subject is a partitive. In matrix clauses, full NP and reciprocal objects pattern together: co-varying agreement is obligatory in both cases.

Matrix clause - Full DP IA

a. İkimiz kitab-1 sev-iyor-uz.

two.of.us book-ACC like-PROG-1PL

'The two of us like the book'

[V: 1PL]

b. * İkimiz kitab-1 sev-iyor-Ø.

two.of.us book-ACC like-PROG-3sG

'The two of us like the book.'

*[V: 3sG]

(20) Matrix clause - Reciprocal IA

a. İkimiz birbir-imiz-i sev-iyor-uz.

two.of.us each.other-1PL.POSS-ACC like-PROG-1PL

'The two of us like each other.'

[rec: 1PL, V: 1PL]

b. * İkimiz birbir-imiz-i sev-iyor-Ø.

two.of.us each.other-1PL.POSS-ACC like-PROG-3sG

'The two of us like each other.'

*[rec: 1PL, V: 3sG]

c. * İkimiz birbir-in-i sev-iyor-Ø.

two.of.us each.other-3sG.POSS-ACC like-PROG-3sG

'The two of us like each other.'

*[rec: 3sG, V: 3sG]

d. * İkimiz birbir-in-i sev-iyor-uz.

two.of.us each.other-3sG.POSs-ACC like-PROG-1PL

'The two of us like each other.'

*[rec: 3sG, V: 1PL]

Now consider nominalized clauses. In nominalized clauses with partitive subjects and full NP internal arguments, default agreement is obligatory and co-varying agreement is impossible; this is the pattern discussed at length in the previous section.

(21) Nominalized clause - Full DP IA

a. * Çocuk [ikimiz-in kitab-1 sev-diğ-imiz ]-i söyle-di.

child two.of.us-GEN book-ACC like-FNMLZ-1PL.POSS -ACC Say-PST

'The child said that the two of us like the book.'

*[V: 1PL $]$ 
b. Çocuk [ikimiz-in kitab-1 sev-diğ-in ]-i söyle-di.

child two.of.us-GEN book-ACC like-FNMLZ-3sg.poss -ACC say-PST

'The child said that the two of us like the book.'

[V: 3sG]

But a remarkable observation emerges when we substitute the full DP object in (21) for a reciprocal: here, co-varying agreement becomes possible alongside default agreement. ${ }^{8}$

Nominalized clause - Reciprocal IA

a. Onlar [ikimiz-in birbir-imiz-i sev-diğ-imiz ]-i

they two.of.us-GEN each.other-1PL.POSS-ACC like-FNMLZ-1PL.POSS -ACC söyledi-ler.

said-PL

'They said that the two of us like each other.'

b. Onlar [ikimiz-in birbir-imiz-i sev-diğ-in ]-i

they two.of.us-GEN each.other-1 PL.Poss-ACC like-FNMLZ-3sG.POss -ACC

söyledi-ler.

said-PL

'They said that the two of us like each other.'

c. * Onlar [ ikimiz-in birbir-in-i $\quad$ sev-diğ-in $\quad$ ]-i
they two.of.us-GEN each.other-3sG.Poss-ACC like-FNMLZ-3sG.POss -ACC söyledi-ler. said-PL

'They said that the two of us like each other.'

d. * Onlar [ikimiz-in birbir-in-i sev-diğ-imiz ]-i

they two.of.us-GEN each.other-3sG.POss-ACC like-FNMLZ-1 PL.POss -ACC söyledi-ler.

said-PL

'They said that the two of us like each other.'

*[rec: 3sG, V: 1PL]

In other words, the requirement for default agreement with certain kinds of subjects is overridden when the nominalized clause contains a bound element. Importantly, even though co-varying agreement becomes grammatical, default agreement does not become ungrammatical: instead, either option is admissible.

Crucially, this pattern of optionality seems to be derived by any bound element, not just reciprocals. For instance, the pattern persists if, instead of a reciprocal, the subject partitive binds a pronoun. ${ }^{9}$

a. Leyla [ikimiz-in tez-ler-imiz-i nihayet bitir-diğ-imiz ]-i

Leyla two.of.us-GEN thesis-PL-1PL.POSS-ACC finally finish-FNMLZ-1PL.POSS -ACC söyle-di-Ø.

say-PST-3sg

'Leyla said that the two of us finally finished our theses.' [BndPro: 1PL, V: 1PL]

\footnotetext{
${ }^{8}$ Some speakers consistently report all (c) examples below to be significantly worse than (a,b), but marginally better than (d).

${ }^{9}$ Thanks to Jaklin Kornfilt for bringing this data point to our attention.
} 
b. Leyla [ikimiz-in tez-ler-imiz-i nihayet bitir-diğ-in ]-i

Leyla two.of.us-GEN thesis-PL-1PL.POSS-ACC finally finish-FNMLZ-3sG.POSS -ACC söyle-di- $\varnothing$.

say-PST-3SG

'Leyla said that the two of us finally finished our theses.' [BndPro: 1PL, V: 3sG]

c. * Leyla [ikimiz-in tez-ler-i-ni nihayet bitir-diğ-in ]-i

Leyla two.of.us-GEN thesis-PL-3sG.POSS-ACC finally finish-FNMLZ-3sG.POSS -ACC söyle-di-Ø.

say-PST-3sG

'L said that the two of us finally finished our theses.' *[BndPro: 3sg, V: 3sG]

d. * Leyla [ikimiz-in tez-ler-i-ni nihayet bitir-diğ-imiz ]-i

Leyla two.of.us-GEN thesis-PL-3SG.POSS-ACC finally finish-FNMLZ-1PL.POSS -ACC söyle-di-Ø.

say-PST-3sG

'L said that the two of us finally finished our theses.' *[BndPro: 3sG, V: 1PL]

Note also that this is not an effect of linear order, as it persists when we scramble the internal argument out of the nominalized clause:

$$
\begin{array}{llll}
\text { Birbir-imiz- } i_{j} & \text { onlar [ ikimiz-in } & t_{j} \text { sev-diğ-imiz } & \text { ]-i öyledi-ler. } \\
\text { each.other-1PL.POSS-ACC they two.of.us-GEN } & \text { like-FNMLz-1 PL.POSs -ACC said-1PL }
\end{array}
$$

'They said that the two of us like each other.'

[rec: 1PL, V: 1PL]

If bound elements in the nominalized clause enable co-varying agreement on the verb, a natural question concerns how local the bound element must be to the verb to trigger this effect. It seems that this relationship need not be extremely local.

In the examples above, co-varying agreement was made possible by a bound element occurring as the internal argument of a transitive verb. The same pattern, however, obtains with dative-marked arguments of unaccusative verbs.

a. Öğretmen [ kura-da ikimiz-in birbir-imiz-e

teacher draw-LOC two.of.us-GEN each.other-1PL.POSS-DAT

çık-tı̆̆-ımız ]-1 söyle-di.

appear-FNMLZ-1PL.POSS -ACC said-3sG

'The teacher said that the two of us matched with each other in the draw.'

b. Öğretmen [ kura-da ikimiz-in birbir-imiz-e

teacher draw-LOC two.of.us-GEN each.other-1PL.POSS-DAT

çık-tığ-ın ]-1 söyle-di.

appear-FNMLZ-3sG.POSS -ACC said-3sG

'The teacher said that the two of us matched with each other in the draw.'

[rec: 1PL, V: 3SG] 
c. * Öğretmen [ kura-da ikimiz-in birbir-in-e

teacher draw-LOC two.of.us-GEN each.other-3sG.POSS-DAT

çık-tığ-ın ]-1 söyle-di.

appear-FNMLZ-3sG.POss -ACC said-3sG

'The teacher said that the two of us matched with each other in the draw.'

*[rec: 3sg, V: 3sg]

d. * Öğretmen [ kura-da ikimiz-in birbir-in-e

teacher draw-LOC two.of.us-GEN each.other-3sG.POSS-DAT

çık-tığ-ımız ]-1 söyle-di.

appear-FNMLZ-1PL.POsS -ACC said-3sG

'The teacher said that the two of us matched with each other in the draw.'

*[rec: 3sG, V: 1PL]

The pattern persists under multiple embeddings. ${ }^{10}$ In the following example, the intermediate nominalized verb can optionally bear co-varying agreement triggered by a reciprocal. However, this reciprocal is not an argument of the intermediate nominalized verb, being instead embedded in a comitative adjunct to that verb.

a. Kemal [ hepimiz-in dün bütün günü birbir-imiz-i

Kemal all.of.us-GEN yesterday whole day each.other-1PL-ACC

öv-mek-le geçir-diğ-imiz ]-i söyle-di- $\varnothing$.

praise-NFNMLZ-COM pass-FNMLZ-1PL.POSS -ACC SAY-PST-3sG

'Kemal said that all of us spent the whole day yesterday praising each other.'

[rec: 1PL, V: 1PL]

b. Kemal [ hepimiz-in dün bütün günü birbir-imiz-i

Kemal all.of.us-GEN yesterday whole day each.other-1PL-ACC

öv-mek-le geçir-diğ-in ]-i söyle-di- $\varnothing$.

praise-NFNMLZ-COM pass-FNMLZ-3sG.POSS -ACC Say-PST-3sG

'Kemal said that all of us spent the whole day yesterday praising each other.'

[rec: 1PL, V: 3sG]

Finally, the effect persists if the bound element is in a co-ordinated NP, regardless of the order of conjuncts.

a. Baba-n [ikimiz-in birbir-imiz ve siz-ler için

father-2sG.Poss two.of.us-GEN each.other-1 PL.POss and you.PL-LER for

yaşa-dığ-ımız ] ]-1 söyle-di- $\varnothing$.

live-FNMLZ-1PL.POSS -ACC Say-PST-3sg

'Your father said that the two of us live for each other and you.'

[rec: 1PL, V: 1PL]

\footnotetext{
${ }^{10}$ We have encountered speakers for whom the data in (26) and (27) patterns differently, with the contrast between the $(a, b)$ and $(c, d)$ examples not being as clear.
} 
b. Baba-n [ikimiz-in birbir-imiz ve siz-ler için father-2sG.POss two.of.us-GEN each.other-1PL.POSS and you.PL-LER for yaşa-dığ-ın ]-1 söyle-di- $\varnothing$.

live-FNMLZ-3sG.POSS -ACC Say-PST-3sG

'Your father said that the two of us live for each other and you.'

c. * Baba-n [ikimiz-in birbir-i ve siz-ler için father-2sG.POss two.of.us-GEN each.other-3sG.POSs and you.PL-LER for yaşa-dığ-ın ]-1 söyle-di- $\varnothing$. live-FNMLZ-3sG.POSS -ACC Say-PST-3sG

'Your father said that the two of us live for each other and you.'

* *[rec: 3sG, V: 3sG] Baba-n [ikimiz-in birbir-i siz-ler için father-2sG.POss two.of.us-GEN each.other-3sG.POSS and you.PL-LER for yaşa-dığ-ımı ] ]-1 söyle-di-Ø. live-FNMLZ-1PL.POSS -ACC Say-PST-3SG

'Your father said that the two of us live for each other and you.'

*[rec: 3sG, V: 1PL]

In summary, in nominalized clauses with a default-triggering subject, default agreement is not the only possibility after all; instead, if the clause contains a bound element, co-varying agreement becomes possible as well. Importantly, the emergence of co-varying agreement does not depend on the bound element being an argument of the nominalized verb.

5. Conclusion: Towards an analysis. We conclude with a set of remarks towards an explanatory analysis of the Turkish facts.

Firstly, a set of observations relevant to the distribution of default agreement in the Turkish nominal domain is the Anaphor Agreement Effect (AAE), a family of phenomena suggesting that anaphors resist being construed in agreeing positions cross-linguistically (Rizzi 1990; Woolford 1999). At this point, it is instructive to consider two sets of analyses that have been proposed to account for the AAE.

Under one kind of analysis, which we will call the structural underspecification approach, anaphors cannot trigger regular agreement because they are structurally deficient. A common view implements this deficiency as lack of phi-features: anaphors begin their derivational life as empty phi-feature bundles that must be valued by another DP (Kratzer 2009; Reuland 2001, 2011). In the semantics, this structural deficiency translates into a referential deficiency; in the syntax, it leads to the inability of anaphors to trigger agreement before they receive phifeatures from their antecedent.

A second analytical possibility is found in structural opacity approach. Under this view, it is not necessary that anaphors be completely devoid of phi-features at the point where agreement takes place. Instead, anaphors are taken to be structurally opaque: phi-features may be present, but the internal structure of anaphors renders these phi-features invisible to operations from outside; Preminger's (2019) phi encapsulation account is a prime example of such an analysis (cf. Abramovitz \& Bassi 2020 for recent discussion). 
(28)

Structural underspecification

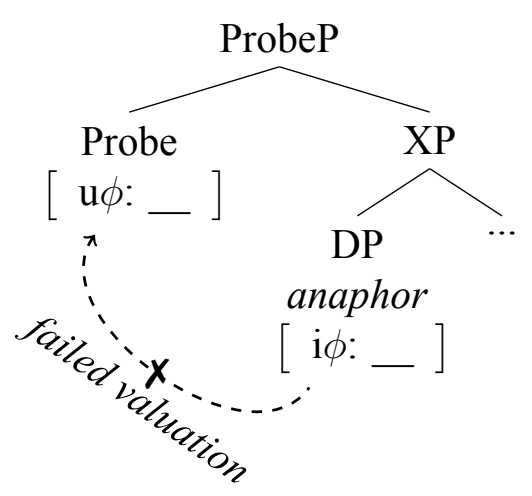

(29)

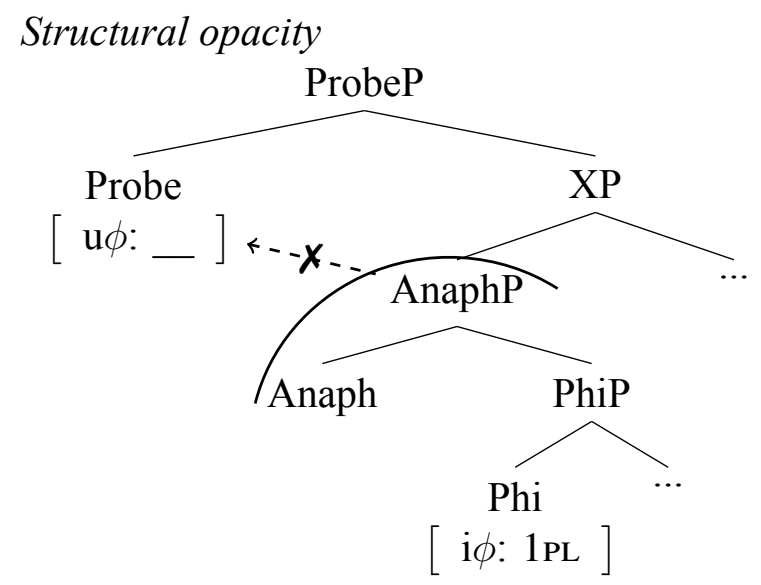

All things being equal, the underspecification approach seems ill-suited to capturing the totality of Turkish data. Recall that pronouns like bizler trigger default agreement; however, under standard assumptions, (referential) pronouns are fully specified for phi-features. Moreover, it is not clear how the underspecification approach would answer Question 2 above: why should partitives, APCs and inflected pronouns be underspecified for phi-features only in the nominal domain? Note also that the link between structural and referential deficiency that justifies underspecification for anaphors does not obtain for the entire class of NPs that trigger default agreement in Turkish. In analyses such as that of Kratzer (2009), it is the lack of phifeatures on anaphors that makes them referentially deficient, and binding is viewed as the process of feature valuation of the anaphor by a higher DP. But partitives, APCs and inflected pronouns are referentially autonomous, weakening the case for a structural underspecification account applied to these data.

On the other hand, our generalization in Section 3 concerning the role of the genitive is an instantiation of the structural opacity approach: genitive case renders some nominal constituents opaque for agreement. We now turn to a specific proposal for how this might be accomplished.

In discussing Turkish partitives and APCs, Sat1k (2020) offers a phase-based implementation of the structural opacity approach. Under this analysis, genitive case assignment projects a $\mathrm{KP}$ layer, where $\mathrm{K}$ is a phase head in Turkish. This analysis assumes that partitives and APCs are embedded in the complement of the phase head; as such, after case has been assigned, they undergo spell-out and are inaccessible for agreement. This analysis also assumes that the phifeatures of pronouns are visible at the edge of KP, such that they will be available for probing. Finally, Sattk (2020) takes nominative case assignment to amount to caselessness (Preminger \& Kornfilt 2015); as such, no KP is projected, and both pronouns and partitives/APCs agree when marked nominative.

Though we consider it encouraging that both this paper and Sattk (2020) have independently arrived at the same descriptive generalization concerning the genitive, the phase-based implementation of this intuition does not seem capable for accounting for the full range of facts. Firstly, some conceptual remarks are in order. The phase-based approach crucially relies on extremely specific assumptions on the nature of case assignment, and on the timing of case assignment relative to agreement. This approach requires that case be assigned to the subject of nominalized clauses before these subjects are probed for agreement; additionally, it requires 
that case assignment be realized as the presence of a KP node in the syntax (or, in any case, at the same level as that where agreement takes place; Bobaljik 2008). Crucially, however, no aspect of the Turkish facts motivates either assumption; it is then not encouraging that, if we were to choose a different (and perhaps more conventional) theory of the relation between case and agreement, the phase-based implementation would simply not work.

Perhaps more importantly, there are empirical reasons that motivate a move away from this phase-based approach. Firstly, recall that the class of default-triggering nominals includes not only partitives and APCs, discussed in Sat1k (2020), but also anaphors and inflected pronouns, not discussed therein. The latter two cases are illuminating. Firstly, under the phasebased approach, anaphors would need to be in a different phase to their antecedent in order to trigger default agreement; this raises the question of how reciprocals, which are local anaphors, are at once capable of being bound and of triggering default agreement. Unless binding across phases is somehow possible, the phase-based analysis makes the wrong prediction here. Secondly, inflected pronouns like bizler also trigger default agreement; if, like their plain pronominal counterparts, they are merged in the edge of KP, they should trigger full agreement, contrary to fact. The possible retort that bizler is simply merged in a different position to regular pronouns merely serves to highlight the fact that no principled reason is given for merging pronouns in a different position to larger NPs.

A different account of the role of the opacifying effect on genitive case would capitalize on the difference in size between pronouns and larger default-triggering nominals. We believe the contrast between regular pronouns (biz) and inflected pronouns (bizler) to be particularly suggestive to this end: it is striking that biz triggers full agreement unless it bears an additional morpheme, at which point it triggers default agreement instead. Perhaps, then, genitive treats pronouns and default-triggering nominals differently not because the two are merged in different positions in the extended nominal projection, but because each realizes a differently sized nominal. In other words, case relates differently to small nominals such as pronouns compared to larger ones. Though this intuition remains to be fleshed out, it receives support from data suggesting that case is 'closer' to pronouns than to full NPs for purposes of suppletion (Smith et al. 2019).

Finally, the facts reported in our Section 4 may have important implications for the relationship between binding and agreement. That binding licenses an otherwise impossible agreement configuration seems fully consonant with the idea that binding is mediated by agreement (Reuland 2001, 2006). At the same time, we note that the relationship is not one-to-one: default agreement remains possible in the binding configurations examined. In other words, the correct generalization does not take the form 'if a default-triggering element binds, it must agree', but rather 'if a default-triggering element binds, it can agree'. Understanding the precise mechanics at play here, alongside the apparent optionality between default and full agreement under binding, is an important direction for the future. Nonetheless, Turkish presents the first case that we know of where binding effects a structural difference on the binder: in Turkish, binding enables full agreement, a possibility otherwise unavailable with default-triggering nominals.

\section{References}

Abramovitz, Rafael \& Itai Bassi. 2020. Weakening a universal: Relativized Anaphor Agreement Effect. Poster presented at the 94th Annual Meeting of the Linguistic Society of 
America.

Aygen, Gulsat. 2007. Syntax and semantics of genitive subject-case in Turkic. California Linguistic Notes 32(2).

Bobaljik, Jonathan David. 2008. Where's phi? agreement as a postsyntactic operation. In

David Adger Daniel Harbour \& Susana Béjar (eds.), Phi theory. 295-328. Oxford: Oxford University Press.

Chomsky, Noam. 1981. Lectures on government and binding. Dordrecht: Foris.

George, L. M. \& Jaklin Kornfilt. 1981. Finiteness and boundedness in turkish. In Frank W.

Heny (ed.), Binding and filtering. 105-128. MIT Press.

Ince, Atakan. 2008. On Default Agreement in Turkish. Manuscript.

Kornfilt, Jaklin. 2001. Local and long-distance reflexives in Turkish. In Peter Cole, Gabriella

Hermon \& C.-T. James Huang (eds.), Long-distance reflexives (Syntax and Semantics 33). 197-226. Waltham, MA: Academic Press.

Kornfilt, Jaklin. 2003. Subject case in Turkish nominalized clauses. In Junghanns, Uwe \& Luka Szucsich (eds.), Syntactic structures and morphological information (Interface Explorations 7). 129-215. Berlin: Mouton de Gruyter.

Kornfilt, Jaklin. 2007. Verbal and nominalized finite clauses in Turkish. In Irina Nikolaeva (ed.), Finiteness: Theoretical and empirical foundations. 305-332. Oxford: Oxford University Press.

Kratzer, Angelika. 2009. Making a pronoun: Fake indexicals as windows into the properties of pronouns. Linguistic Inquiry 40(2). 187-237. https://doi.org/10.1162/ling.2009.40.2.187.

Legate, Julie, Faruk Akkuş, Milena Šereikaite \& Don Ringe. 2019. On passives of passives. Re-submitted, Language.

Preminger, Omer. 2019. The Anaphor Agreement Effect: further evidence against binding-asagreement. Manuscript, University of Maryland at College Park.

Preminger, Omer \& Jaklin Kornfilt. 2015. Nominative as no case at all: An argument from raising-to-ACC in Sakha. In Andrew Joseph \& Esra Predolac (eds.), Proceedings of the 9th workshop on Altaic formal linguistics, vol. 76, 109-120. Cambridge Mass.: MITWPL.

Reuland, Eric. 2001. Primitives of binding. Linguistic Inquiry 32(3). 439-492. https://doi.org/10.1162/002438901750372522.

Reuland, Eric. 2006. Agreeing to bind. In H. Broekhuis, N. Corver, R. Huybregts, U. Kleinhenz \& J. Koster (eds.), Organizing grammar: studies in honor of Henk van Riemsdijk, 505-513. The Hague: Mouton de Gruyter.

Reuland, Eric. 2011. Anaphora and language design. Cambridge, Mass: MIT Press.

Rizzi, Luigi. 1990. On the anaphor-agreement effect. Rivista di Linguistica 2. 27-42.

Satık, Deniz. 2020. Turkic genitive case and agreement asymmetries. Manuscript, Harvard University.

Smith, Peter W., Beata Moskal, Ting Xu, Jungmin Kang \& Jonathan David Bobaljik. 2019. Case and number suppletion in pronouns. Natural Language \& Linguistic Theory 37(3). 1029-1101. https://doi.org/10.1007/s11049-018-9425-0.

Woolford, Ellen. 1999. More on the Anaphor Agreeement Effect. Linguistic Inquiry 30(2). 257-287. https://doi.org/10.1162/002438999554057. 